Primož Šterbenc

Univerza na Primorskem,

Fakulteta za management primoz.sterbenc@fm-kp.si

\section{Nastajanje multipolarne globalne ureditve in vloga LR Kitajske}

\begin{abstract}
Mednarodni red se spreminja iz unipolarnega $\mathrm{v}$ multipolarnega, kar pomeni da sistem, v katerem obstaja ena supersila (ZDA), postopoma prehaja v sistem, v katerem obstaja večje število velikih sil, med katerimi je najmočnejša Kitajska, ki svojo ogromno ekonomsko moč spreminja v vojaško. Nastaja specifična situacija, zaradi katere bi lahko prišlo do spopada med ZDA in Kitajsko, sprožilec pa bi bila lahko Tajvan in položaj v Južnokitajskem morju. Kitajska tudi izvaja projekt "Pobude pasu in ceste«, s katerim želi uveljaviti svoje ekonomske, (geo)politične in varnostne interese. Peking si tudi prizadeva ekonomsko integrirati Evrazijo, z namenom pridobitve vodilnega položaja $\mathrm{v}$ mednarodnih odnosih.
\end{abstract}

Ključne besede: multipolarnost, Kitajska, Pobuda pasu in ceste

\section{The Emergence of the Multipolar Global Order and the Role of the People's Republic of China}

There has been the process of transformation of unipolar into multipolar international order in which the system with one superpower (the US) has been superseded by the system consisting of several great powers, primarily China. Beijing has been transforming its enormous economic power into military power and consequently there has been possibility of confrontation between the US and China, triggered by Taiwan and the South China Sea. China has also been implementing the "Belt and Road Initiative«, aimed at promotion of its economic, (geo)political, and security interests. Moreover, Beijing wants to economically integrate Eurasia, in order to attain leading position in international relations.

Keywords: multipolarity, China, Belt and Road Initiative

(cc)BY-SA https://doi.org/10.26493/1854-4231.16.31-38

\section{Prehod iz unipolarne v multipolarno \\ globalno ureditev in dvig L $\mathbf{R}$ Kitajske}

Živimo v časih, v katerih se dogajajo bistvene in celo odločilne spremembe $\mathrm{v}$ razporeditvi moči $\mathrm{v}$ mednarodnih odnosih. Potem ko je po koncu hladne vojne na začetku 9o. let prejšnjega stoletja globalna ureditev očitno postala unipolarna, kar je pomenilo, da je bila moč skoncentrirana v rokah ene same supersile - Združenih držav Amerike (ZDA), pa že vse od prve polovice novega tisočletja (kot nekakšno začetno točko je mogoče opredeliti ameriško vodeni napad na Irak leta 2003, ki je zaradi nelegalnosti in nelegitimnosti močno škodil ugledu ZDA) poteka proces, v katerem se globalna ureditev postopoma spreminja iz unipolarne v multipolarno, kar pomeni, da namesto ureditve s prevlado ene same supersile nastaja ureditev $\mathrm{z}$ večjim številom velikih sil. V nastajajoči multipolarni ureditvi se poleg ZDA kot velike sile uveljavljajo Ljudska republika Kitajska (LR Kitajska), Ruska federacija, Indija in Brazilija, v manjši meri pa tudi Evropska unija (Cox 2017, 70; Hurrell 2017, 84-89; Schulze 2018, 7).

Pri tem je treba še posebno pozornost nameniti LR Kitajski, katere moč v zadnjih štirih desetletjih narašča tako hitro, da bi to lahko vodilo v vojaški konflikt med to državo in ZDA. Nastaja namreč nevaren položaj, ki je že v petem stoletju pred našim štetjem povzročil izbruh peloponeške vojne med Atenami in Šparto, tudi v zadnjih 500 letih pa je tako rekoč praviloma povzročal vojne. Gre za stanje, ko se soočata "vzpenjajoča se sila«, ki želi zaradi svoje naraščajoče moči pridobiti bistveno več vpliva v mednarodnih odnosih, in "vladajoča sila", ki želi ohraniti status quo, na podlagi katerega je sama dolgo časa imela prevladujoč položaj. Tovrsten strukturni položaj, v katerem obstaja realna možnost spopada med vzpenjajočo 
se in vladajočo silo, je v svojem delu Peloponeška vojna opredelil veliki atenski zgodovinar Tukidid (1958), seveda pa lahko $\mathrm{v}$ današnjem času povzroči vojno med ZDA (vladajoča sila) in LR Kitajsko (vzpenjajoča se sila) (Allison 2015). Tudi znanost o mednarodnih odnosih opozarja, da so obdobja, v katerih prihaja do velikih sprememb v porazdelitvi moči $\mathrm{v}$ mednarodnih odnosih, težavna in nevarna. Države, ki se vzpenjajo, seveda želijo spremeniti status quo in preoblikovati prevladujoče norme sistema, tako da bi služile njihovim interesom. Po drugi strani so države, ki so vodilne, v skušnjavi, da bi uporabile (tudi vojaško) silo, z namenom, da bi blokirale uveljavljanje revizionističnih držav (Hurrell 2017, 92).

\section{Možnost spopada med ZDA in LR Kitajsko}

Razlog, ki bi lahko najhitreje pripeljal do vojaškega spopada med ZDA in LR Kitajsko, je Tajvan. Peking namreč $\mathrm{v}$ zadnjih letih $s$ svojo retoriko in krepitvijo vojaških kapacitet kaže, da postaja zmeraj nestrpnejši glede uresničitve cilja, ki si ga je zadal že pred mnogimi desetletji - priključitve otoka k »matični Kitajski«. LR Kitajska tako pospešeno krepi svoje vojaške kapacitete za invazijo na Tajvan, pri čemer se osredotoča na orožje, ki bi lahko nevtraliziralo zanjo najnevarnejše ameriške vojaške zmogljivosti (letalonosilke, podmornice in komunikacijski sateliti). Vendar pa ZDA po drugi strani tudi vse bolj odločno sporočajo, da bodo $\mathrm{v}$ primeru kitajskega napada branile otok, pri čemer si prizadevajo za oblikovanje širše protajvanske koalicije, ki bi prvenstveno vključevala Japonsko, ki ima zaradi svoje odvisnosti od uvoza energentov skozi Južnokitajsko morje strateški interes za neodvisnost Tajvana. Američani morebitnemu spopadu za Tajvan pridajajo izjemen pomen, saj se zavedajo, da bi kitajska osvojitev otoka prizadejala velik udarec zaupanju azijskih držav v voditeljsko vlogo ZDA na jugovzhodnoazijsko-pacifiškem območju. L R Kitajska želi z osvojitvijo Tajvana med drugim pridobiti nadzor nad izredno pomembno plovno potjo, ki vodi od Malajske ožine prek Južnokitajskega morja do Japonske. Poleg tega tajvansko podjetje Taiwan Semiconductor Manufactoring Company (TSMC) izdela 84 odstotkov vseh najbolj sofisticiranih polprevodnikov (čipov) v svetu, ki so nujno potrebni za proizvodnjo vseh vrst tehnoloških naprav in tudi električnih avtomobilov; LR Kitajska mora te polprevodnike, tako kot ZDA, uvažati (Dyer 2014, 46-47; "Living on the Edge« 2021; Medcalf 2020, 153; "Something Wicked This Way Comes« 2021).
Drugi razlog, ki bi lahko v bližnji prihodnosti povzročil oborožen incident in morda celo spopad med LR Kitajsko in ZDA, je želja po prevladi v Južnokitajskem morju. Peking namreč trdi, da ima pravico do nadzora nad skoraj celotnim obsegom tega morja, posledično pa vedno agresivneje nastopa $v$ njem, pri čemer s spreminjanjem posameznih čeri v umetne otoke in vzpostavljanjem vojaških oporišč na njih polagoma širi območje svoje prisotnosti. S tem zaostruje napetosti v odnosih z okoliškimi manjšimi državami (Vietnam, Malezija, Filipini), s katerimi je v ozemeljskih sporih zaradi otočij Paracel in Spratly. ZDA po drugi strani sporočajo, da LR Kitajski ne bodo dovolile, da bi si prilaščala Južnokitajsko morje, predvsem s poudarjanjem, da skozi to morje vodijo mednarodne plovne poti; Washington $\mathrm{z}$ namenom uveljavljanja tega stališča tja pošilja vojaške ladje, s tem pa se povečuje možnost trka $\mathrm{z}$ vse močnejšima kitajsko vojno mornarico in priobalno stražo. Ob tem je treba poudariti, da je LR Kitajska leta 2020 postala prva država, ki je po drugi svetovni vojni prehitela ZDA po kriteriju velikosti vojne mornarice (število plovil), poleg tega pa ima tudi največjo priobalno stražo na svetu. Washington bo pri zasledovanju svojih ciljev lahko vedno bolj izkoriščal odpor manjših okoliških držav do agresivne LR Kitajske, poleg tega pa v zadnjem času naglo razvija vojaško zavezništvo z Japonsko, Avstralijo in Indijo v okviru Quadrilateral Security Dialogue (»Quad“) (»AI, Captain « 2020; Dyer 2014, 88-96; »Great White Hulls« 2020; Maçães 2018, 121).

\section{Ekonomski vzpon LR Kitajske}

Kot v svojem delu The Rise and Fall of the Great Powers: Economic Change and Military Conflict from 1500 to 2000 poudarja Paul Kennedy (1987 po Hurrell 2017, 92), politična in vojaška moč neke države, ki želi preoblikovati obstoječo ureditev mednarodnih odnosov, vedno izhajata iz njene ekonomske moči. Tudi izjemna krepitev politične in vojaške moči LR Kitajske to potrjuje, saj se je le-ta $v$ zadnjih štirih desetletjih spremenila iz revne države $\mathrm{v}$ ekonomsko supersilo. $\mathrm{V}$ času, ko je bil na čelu komunistične Kitajske dolgoletni voditelj Mao Cetung (1949-1976), ki je dogmatsko zagovarjal komunistični, centralnoplanski ekonomsko-socialni sistem, se država nikakor ni mogla izviti iz revščine in obrazca zgolj zelo počasnega industrijskega razvoja, v zadnjem obdobju Maove vladavine pa je tudi vse bolj nazadovala na kmetijskem, ekonomskem, vojaškem in znanstvenem področju. Po Maovi smrti (1976) in na- 
stopu novega voditelja, Deng Xiaopinga, pa je država stopila na pot osupljivo hitrega razvoja. Decembra 1978 so začeli uresničevati reformni program »štirih modernizacij« (na kmetijskem, ekonomskem, vojaškem in znanstveno-tehničnem področju), na podlagi katerega je LR Kitajska naglo vstopala v kapitalistično družbeno-ekonomsko ureditev. V tem okviru so v priobalnih pokrajinah (Guangdong, Fudžian) vzpostavili »svobodna ekonomska območja« (deregulirana območja brez davkov in socialne zaščite delavcev), kamor so najprej privabili kapital poslovnežev iz zelo številne kitajske diaspore v jugovzhodni Aziji (Malezija, Singapur, Tajska), nato pa še zahodne multinacionalne korporacije, ki so svojo proizvodnjo hvaležno selile v svet poceni delovne sile (Calder 2019, 50-53, 102).

Ekonomski oziroma materialni rezultati kitajskega prehoda v kapitalizem so (bili) fantastični. Država je imela v obdobju 1980-2015 vsako leto dvoštevilčno ekonomsko rast, zato je bila kitajska ekonomija leta 2015 kar več kot 30-krat večja, kot je bila leta 1980. Ekonomska rast je do približno leta 2008 temeljila na izvozu (Evropa, Japonska, ZDA, jugovzhodna Azija) iz priobalnih pokrajin, od takrat pa skušajo uveljaviti rast na podlagi povečevanja domačega povpraševanja, predvsem v notranjosti države, tudi z velikimi ekonomskimi stimulusi (na primer 586 milijard dolarjev leta 2008). LR Kitajska je bila po kriteriju nominalnega bruto družbenega proizvoda še leta 1980 na 12. mestu v svetu, leta 2010 pa se je že prebila na drugo mesto (takoj za ZDA), s katerega je izpodrinila Japonsko. Leta 2013 je po kriteriju bruto družbenega proizvoda, merjenega s pariteto kupne moči, celo prehitela ZDA in stopila na prvo mesto. Država je postala največja svetovna industrijska proizvajalka in izvoznica, poleg tega pa ima največje devizne rezerve na svetu (Calder 2019, 87, 101-103, 105).

\section{Mednarodno delovanje LR Kitajske kot velike sile}

Ko je LR Kitajska zaradi hitrega ekonomskega razvoja postajala velika sila, je tudi začela delovati kot druge velike sile, vključno z $\mathrm{zDA}, \mathrm{v}$ novejši zgodovini. Tako kot so ZDA na prelomu iz 19. v 20. stoletje zaradi svoje ekonomske moči, temelječe na razvoju težke industrije in infrastrukture v drugi industrijski revoluciji, načrtno zgradile močno vojno mornarico in pridobivale nadzor nad bližnjimi morji (predvsem nad Karibskim morjem in Pacifikom, vključno z izgradnjo Panamskega prekopa v letih 1908-1914), se je tudi LR Kitajska začela podajati na morje, graditi močno vojno mornarico in si prvenstveno prizadevati za pridobitev nadzora nad bližnjim Južnokitajskim morjem. In tako kot je Washington na začetku 20. stoletja sledil nasvetom enega od največjih geopolitikov, Alfreda Thayerja Mahana (1987), ki je v svojem znamenitem delu The Influence of Sea Power Upon History: 1660-1783 (prvič objavljeno leta 189o) argumentiral, da vpliv držav izhaja iz njihove pomorske moči ter da morajo velike sile zgraditi močna vojna ladjevja in pridobiti nadzor nad bližnjimi in tudi drugimi zanje pomembnimi morji, tako danes tudi kitajske intelektualne, politične in vojaške elite sugestijam ameriškega geopolitika pridajajo izjemen pomen. Prizadevanja LR Kitajske za nadzor nad Južnokitajskim morjem ter za osvojitev Tajvana motivira tudi njen občutek geografske oziroma geostrateške utesnjenosti, kajti, tudi objektivno gledano, kitajski izhod na globoka morja ovira "prva otoška veriga«, ki jo tvorijo proameriški Japonska, Tajvan, Filipini in Malezija (Benko 1997, 114-122; Dyer 2014, 23-29; Mahan 1987).

Za razumevanje odločenosti LR Kitajske, da bo postala velika vojaška sila in si pridobila nadzor nad Južnokitajskim morjem, in to kljub nasprotovanju ZDA, pa je treba poznati nacionalistične korenine tovrstnega kitajskega razmišljanja, ki izvira iz nevralgične novejše zgodovine. V kitajski kolektivni nacionalni zavesti je namreč močno zasidran spomin na "stoletje nacionalnega ponižanja«. Gre za obdobje med letoma 1839 in 1949, v katerem so ostarelo imperialno Kitajsko zaradi njene šibkosti zahodne sile, na čelu z Veliko Britanijo, večkrat vojaško porazile ter si jo politično in ekonomsko podredile. $V$ dveh »opijskih vojnah" (1839-1842 in 1856-1860) ter med »boksarsko vstajo" (1898-190o) so zahodne sile pokazale svojo vojaško premoč, Kitajsko pa so prisilile, da se je odprla za prihod zahodnega blaga ter pristala na neenakopravno trgovino. ${ }^{1}$ Nenazadnje so si Britanci v tem času prisvojili Hongkong, in kar je še pomembneje, $z$ uničenjem Poletne palače, simbola veličastnosti zadnje kitajske dinastije Čing, so Kitajsko globoko ponižali. Tega Kitajci niso nikoli pozabili. Za večje razumevanje

\footnotetext{
${ }^{1}$ Medtem ko je pred "stoletjem nacionalnega ponižanja« kitajski bruto družbeni proizvod tvoril 33 odstotkov svetovnega bruto družbenega proizvoda, pa je v času evropske nadvlade padel zgolj na pet odstotkov svetovnega outputa. Tudi kitajski dohodek na glavo prebivalca je padel z 90 na 20 odstotkov svetovnega povprečja (Lawson 2017, 49).
} 
napetosti $\mathrm{v}$ današnjih odnosih med LR Kitajsko in Japonsko je treba dodati, da se je med "stoletjem nacionalnega ponižanja« evropskim silam pri njihovem podrejanju Kitajske pridružila tudi imperialna Japonska, ki je v obdobju »Meidži« (1868-1912) zaradi svoje vesternizacije postala velika sila ter je v naslednjih treh desetletjih izvajala ozemeljsko agresijo nad Kitajsko, vključno z zagrešitvijo hudih vojnih zločinov nad Kitajci med drugo svetovno vojno. $\mathrm{V}$ zadnjih desetletjih odnose med državama vse bolj obremenjuje dejstvo, da se na Japonskem krepijo revizionistične tendence, ki zanikajo ali zmanjšujejo težo japonskih zločinov med drugo svetovno vojno. Ob tem je treba opozoriti, da današnje odnose med Pekingom in Tokiom vendarle najneposredneje obremenjuje ozemeljski spor zaradi otočja Senkaku (Diaoju) v Vzhodnokitajskem morju (Dyer 2014, 145-164; Welch Larson in Shevchenko 2019, 5254, 207-208).

LR Kitajska geopolitičnim sugestijam Alfreda Thayerja Mahana ne sledi zgolj na bližnjih morjih, temveč se $\mathrm{v}$ skladu $\mathrm{z}$ njimi podaja tudi na oddaljena morja. Mahan je namreč poudaril, da morajo velike sile nadzorovati pomorske poti, ki so življenjsko pomembne za njihove ekonomije. Za Peking ima takšen vitalen pomen pomorska pot, ki vodi skozi Indijski ocean, nato pa skozi Malajsko ožino in Južnokitajsko morje prispe do samega kitajskega ozemlja. LR Kitajska, ki zaradi eksplozivne ekonomske rasti $\mathrm{v}$ zadnjih desetletjih potrebuje ogromne količine energentov, je leta 2017 postala največja svetovna uvoznica surove nafte, črno zlato pa v največji meri kupuje $\mathrm{v}$ državah Perzijskega zaliva in v Afriki. Azijska velikanka tudi že dolgo na svojem ozemlju ne more več pridelati dovolj hrane za svoje prebivalstvo, zato si je v zadnjih dveh desetletjih preskrbo zagotovila na takšen način, da najema zemljo za kmetijsko proizvodnjo, predvsem v Afriki. S »črnega kontinenta « uvaža tudi strateške rudnine in les. ${ }^{2}$ Zaradi vsega tega je za LR Kitajsko neoviran pomorski promet skozi Indijski ocean geostrateška prioriteta, posledično pa Peking v zadnjih dveh desetletjih postopoma vzpostavlja globokomorsko ladjevje in verigo pristanišč (potencialnih pomorskih oporišč) ob Indijskem oceanu: Čaukpju v Mjanmarju, Gvadar v Pakistanu, Hambantota na

\footnotetext{
${ }^{2} \mathrm{~V}$ Afriki sicer $\mathrm{v}$ zadnjih dveh desetletjih poteka "nova tekma za Afriko", v kateri sodelujejo prvenstveno L R Kitajska na eni ter zahodne države (ZDA in nekdanje evropske kolonialne sile) na drugi strani (Šterbenc 2012).
}

Šrilanki in Cox's Bazar v Bangladešu. Leta 2017 je LR Kitajska tudi vzpostavila svoje prvo prekomorsko vojaško oporišče, in sicer v geopolitično pomembnem Džibutiju (Calder 2019, 119; Dyer 2014, 53-63; Hillman 2020, 174; Metcalf 2020, 205; Šterbenc 2012, 14-15).

\section{"Pobuda pasu in ceste»}

Mogoče je reči, da LR Kitajska v zadnjem desetletju izvaja največji oziroma najambicioznejši projekt v današnjih mednarodnih odnosih, to je "Pobuda pasu in ceste« (P P C). ${ }^{3}$ Gre za orjaški projekt, v okviru katerega naj bi Peking investiral 1 trilijon (1.0oo milijard) dolarjev v novo (kopensko in pomorsko) transportno in trgovinsko infrastrukturo (ceste, železnice, električna omrežja, naftovodi in plinovodi, pristanišča in drugo) med LR Kitajsko in ostalim svetom, predvsem preko nudenja kreditov drugim državam. ${ }^{4}$ Projekt je kitajski predsednik Xi Jinping predlagal oziroma razglasil septembra in oktobra 2013 med obiskoma v Kazahstanu in Indoneziji, pri čemer je argumentiral, da je treba oživiti znamenito starodavno "Svilno cesto«, ki je obstajala med drugim stoletjem pred našim štetjem in 16. stoletjem ter je trgovinsko povezovala ogromno območje med Kitajsko in Evropo. ${ }^{5}$ PPC se je že do leta 2018 pridružilo prek 80 držav (iz srednje Azije, južne in jugovzhodne Azije, Bližnjega vzhoda, vzhodne Evrope, Afrike in Karibov; pridružila se je tudi Turčija) (Calder 2019, 26-29, 43-44; Frankopan 2019, 87-88, 91; International Crisis Group 2017, 2).

P PC vsebuje dva poglavitna sestavna dela, in sicer »Ekonomski pas svilne ceste« in »Pomorsko

\footnotetext{
${ }^{3}$ Projekt je bil ob začetku imenovan »En pas, ena cesta«, leta 2015 pa so ga Kitajci preimenovali v »Pobudo pasu in ceste" (Frankopan 2019, 91; International Crisis Group 2017, 2).

${ }^{4}$ Sredi leta 2015 je Kitajska razvojna banka razglasila, da je rezervirala 890 milijard dolarjev za financiranje 900 projektov, večinoma povezanih s transportom, z infrastrukturo in energijo. Šest mesecev pozneje je Kitajska izvozno-uvozna banka razglasila, da je v okviru PPC začela financirati več kot 1.000 projektov v 49 državah (Frankopan 2019, 90-91).

${ }^{5}$ Prvi popotnik na »Svilni cesti« je bil v drugem stoletju pred našim štetjem Žang Kian, ki ga je kitajska dinastija Han kot odposlanca poslala v srednjo Azijo, da bi tam za njeno konjenico priskrbel močne, hitre in vzdržljive konje, ki so jih gojili v srednjeazijski stepi. Prvi trgovinski quid pro quo je temeljil na izmenjavi elegantne kitajske svile za srednjeazijske konje (Calder 2019, 25-26).
} 
svilno cesto za 21. stoletje ${ }^{6}{ }^{6} \mathrm{Za}$ "Ekonomski pas svilne ceste«, ki poteka po kopnem, je predviden potek po naslednji osrednji geografski trasi: od Ksiana v LR Kitajski preko srednje Azije, Irana, Turčije in Rusije do srednje in vzhodne Evrope ter končno zahodne Evrope. Posamezni kopenski kraki pa naj bi vodili tudi do Perzijskega zaliva, Bližnjega vzhoda in Indokine. V tem okviru je Peking predvidel osrednji koridor (»Novi evrazijski koridor prek kopenskega mostu«) in dodatnih pet ekonomskih koridorjev. ${ }^{7} \mathrm{Za}$ "Pomorsko svilno cesto za 21. stoletje«, ki poteka prek morij, pa je predviden potek po dveh geografskih trasah. Zahodna trasa vodi od LR Kitajske prek Južnokitajskega morja, Bengalskega zaliva in Indijskega oceana do vzhodnoafriške obale (Kenija), nato pa naprej skozi Rdeče morje in Sueški prekop do Sredozemlja, v katerem je vstopna točka na evropski kontinent grško pristanišče Pirej pri Atenah. ${ }^{8}$ Vzhodna trasa vodi od LR Kitajske prek Južnokitajskega morja v južni Pacifik. V tem okviru je predvidena tudi (kitajska) izgradnja več pristanišč in (vojaških) oporišč, vključno z že omenjenimi pristanišči na Šrilanki ter v Pakistanu, Mjanmarju in Bangladešu ter vojaškim oporiščem v Džibutiju (Calder 2019, 44; Maçães 2018, 52, 62).

Čeprav P PC kot "pobuda« vsebuje malo konkretnih ciljev, poleg tega pa nima institucionalne strukture, je možno na podlagi objektivnih kontekstov in nekaterih stališč, ki so jih izrazili kitajski uradniki, argumentirati, da želi LR Kitajska s tem projektom doseči naslednje cilje:

Ekonomski cilj je spodbuditev kitajske ekonomije s pridobitvijo novih trgov in $\mathrm{z}$ ustvarjanjem

\footnotetext{
${ }^{6}$ LR Kitajska sicer mnogo manj formalno načrtuje tudi vzpostavitev »Polarne svilne ceste«, ki naj bi potekala prek arktičnih pomorskih poti (Calder 2019, 145-147; Maçães 2018, 62).

${ }^{7}$ Gre za naslednje ekonomske koridorje: Kitajska-Mongolija-Rusija, Kitajska-srednja Azija-zahodna Azija, Kitajska-Indokina, Kitajska-Pakistan in BangladešKitajska-Indija-Mjanmar (Maçães 2018, 52).

${ }^{8}$ Kitajsko ladjarsko-transportno podjetje China Ocean Shipping Company (cosco) je leta 2016 kupilo oziroma pridobilo večinski delež v pristanišču Pirej. Od leta 2009 je cosco v pristanišče vložil pet milijard dolarjev. Zaradi kitajskega trgovinskega transporta prek Indijskega oceana in Sueškega prekopa je pristanišče postalo sedmo najbolj delovno obremenjeno kontejnersko pristanišče v Evropi. LR Kitajska želi zgraditi železnico od Aten prek Skopja in Beograda do Budimpešte (»Kopensko-pomorski ekspres«). cosco je sicer tretje največje ladjarsko-transportno podjetje na svetu, takoj za podjetjema APM-Maersk in Mediterranean Shipping Co. (Calder 2019, 112, 175-177, 275).
}

povpraševanja po kitajski presežni proizvodnji jekla in aluminija. ${ }^{9}$ Več poslov naj bi dobile tudi kitajska gradbena in druge industrije. LR Kitajska želi postati poglavitni trgovinski in investicijski partner za evrazijske države, poleg tega pa želi odpreti nove poti za trgovino z Evropo (International Crisis Group 2017, 2-3).

Geopolitični cilj je izboljšanje odnosov z državami na kitajski periferiji, poleg tega pa splošna razširitev kitajskega političnega vpliva. LR Kitajska želi uveljavljati kitajsko inačico globalizacije, ki naj bi se od zahodne razlikovala po tem, da naj ne bi uničevala drugih (nezahodnih) civilizacij oziroma kultur, poleg tega pa naj ne bi povečevala neenakosti med posameznimi deli sveta. LR Kitajska se tudi želi prikazati kot mladostna sila, ki je sposobna narekovati dnevni red v mednarodnih odnosih (Calder 2019, 46; International Crisis Group 2017, 3).

Ideološki cilj je uveljavitev kitajskega razvojnega modela, ki temelji na velikih investicijah države v infrastrukturo. Kitajski razvojni model naj bi uveljavljal javne dobrine in trajnostni razvoj, poleg tega pa naj bi bil usmerjen $v$ sodelovanje $z$ namenom koristi za vse udeležene strani (»winwin sodelovanje«). Primer same LR Kitajske naj bi dokazoval, da takšen razvojni model odpravlja revščino. ${ }^{10}$ Mogoče je argumentirati, da kitajski razvojni model de facto pomeni izziv zahodnemu razvojnemu modelu, ki poudarja strukturne in politične reforme ter nudenje tehnične pomoči na področjih zdravstva in izobraževanja, večinoma pa ne govori o gradnji javne infrastrukture za ekonomsko rast (Calder 2019, 46; Frankopan 2019, 93; International Crisis Group 2017, 3).

Geostrateška oziroma varnostna cilja sta predvsem dva. Prvič, LR Kitajska si želi zagotoviti alternativne izvozno-uvozne poti ter poti za preskrbo $z$ energenti, na ta način pa zmanjšati svojo odvisnost od strateških plovnih poti v jugovzho-

\footnotetext{
${ }^{9}$ Eden od najneposrednejših razlogov za lansiranje PPC je bil ta, da je LR Kitajska okoli leta 2010 začela ugotavljati, da je njena proizvodnja surovega jekla ob upoštevanju potreb prevelika. Zmanjšati bi jo morala za četrtino, kar pa bi povzročilo brezposelnost 800.000 delavcev v jeklarski industriji ter izgubo 120 milijard dolarjev. Zato so se kitajske oblasti raje odločile za neokeynesijansko obarvano pobudo, ki bi v drugih državah povečala potrebe po kitajskem surovem jeklu (Calder 2019, 108-110).

${ }^{10}$ Frankopan $(2019,93)$ ugotavlja, da je razvoj LR Kitajske po letu 1980 dejanski dokaz, da politika in razvoj infrastrukture odpravljata revščino.
} 
dni Aziji. ${ }^{11}$ In drugič, kitajske oblasti želijo zagotoviti območje stabilnosti na obeh straneh kitajske zahodne meje, še posebej v kitajski severozahodni pokrajini Ksindžiang, kjer živi okoli deset milijonov pripadnikov turško-muslimanskega ljudstva Ujgurov, ki je zgodovinsko in kulturno močno povezano s srednjo Azijo. V Ksindžiangu se namreč hitro povečujejo napetosti med avtohtonimi Ujguri in Kitajci-Hani, ki jih kitajske oblasti intenzivno naseljujejo v pokrajini. Ekonomski razvoj pokrajine naj bi zmanjševal napetosti. Nenazadnje LR Kitajska želi vodstva srednjeazijskih držav (ki so z izjemo Tadžikistana etnično turške in s tem sorodne Ujgurom) v okviru P P C z ugodnimi krediti nekako podkupiti, da ne bi izražala nezadovoljstva s kitajskimi vse bolj represivnimi politikami v pokrajini (International Crisis Group 2017, 5; »The Beast from the East «, 2020). ${ }^{12}$

\section{Pomikanje proti vodilni vlogi L R Kitajske v mednarodnih odnosih?}

Več analitikov argumentira, da je končni cilj P PC oblikovanje mednarodnega reda, $\mathrm{v}$ katerem bi imela LR Kitajska vodilno vlogo. ${ }^{13}$ In zares je mogoče na podlagi treh vidikov delovanja Pekinga sklepati, da želi azijska velikanka postati vodilna

${ }^{11}$ Kitajsko vodstvo se najbolj boji, da bi $\mathrm{v}$ primeru spopada med ZDA in LR Kitajsko Američani blokirali Malajsko, Sundsko in Lomboško ožino, skozi katere (lahko) plujejo tankerji, ki prek Indijskega oceana dovažajo nafto LR Kitajski. Zato skoraj panično išče možne rešitve. Ena od teh je povečevanje kitajske preskrbe $z$ energenti (nafta, zemeljski plin) preko (kopenskih) naftovodov in plinovodov, ki vodijo iz Ruske federacije in srednje Azije (Kazahstan, Turkmenistan). Kitajsko vodstvo razmišlja tudi o tem, da bi tankerji, ki LR Kitajski dovažajo nafto iz Perzijskega zaliva, lahko zapluli v strateška pristanišča v Pakistanu (Gvadar) in Mjanmarju (Čaukpju), od tam pa naj bi nafta po naftovodih prispela do kitajskega ozemlja. Na ta način bi se izognili transportu prek jugovzhodnoazijskih ožin (Calder 2019, 143-144; Dyer 2014, 52-53, 61; Hillman 2020, 144; Maçães 2018, 21-22).

${ }^{12}$ Zaradi hitrega priseljevanja Hanov v Ksindžiang in drugih kitajskih pritiskov se Ujguri že dolgo počutijo ogrožene, to pa je v letih 2013-2014 že pripeljalo do ujgurskih terorističnih napadov v Pekingu in Kunmingu. Kitajske oblasti so na to odgovorile s politiko »udari močno«, s katero so zelo povečale represivne ukrepe $\mathrm{v}$ pokrajini (nadzor prek vseprisotne moderne tehnologije in varnostno-policijski pritisk) (International Crisis Group 2017, 5-6).

${ }^{13}$ Gre za naslednje analitike: Tom Miller, Nadège Rolland, Chris Devonshire-Ellis, William A. Callahan in Lan Shuen (International Crisis Group 2017, 3-4). sila v svetu. Prvič, LR Kitajska se v okviru »Ekonomskega pasu svilne ceste« očitno želi vse močneje ekonomsko in politično pozicionirati v srednji in vzhodni Evropi, najbolj očitno prek »Okvira za sodelovanje $16+1$ « (od leta $2019 » 17+1 \ll)$, ki ga je začela razvijati že leta 2012. V tem okviru, v katerem sodeluje tudi Republika Slovenija, se redno srečujejo voditelji držav in vlad ali drugi visoki uradniki 16 srednje- in vzhodnoevropskih držav (od leta 2019 tudi Grčije) ter LR Kitajske, in sicer $\mathrm{z}$ namenom sodelovanja na področjih trgovine, investicij in predvsem izgradnje infrastrukture. Peking na ta način precej očitno sledi napotkom verjetno najeminentnejšega geopolitika $\mathrm{v}$ zgodovini, Britanca sira Halforda Mackinderja, ki je v svojem delu Democratic Ideals and Reality (1919) utemeljeval, da bo tista država, ki bo nadzorovala vzhodno Evropo (ozemlje med Baltiškim in Črnim morjem ter med reko Labo in Jadranskim morjem), posredno vladala celotnemu svetu. ${ }^{14}$ LR Kitajska ni sama v tovrstnem prizadevanju, ${ }^{15}$ saj tudi ZDA precej očitno kažejo, da želijo pridobiti nadzor nad vzhodno Evropo. ${ }^{16}$ Res pa je, da je v zadnjem letu »Okvir za sodelovanje $17+1$ « zaradi vse večjega razočaranja srednje- in vzhodnoevropskih držav nad neuresničenimi obljubami LR Kitajske (glede naložb ter spoštovanja standardov varstva okolja in človekovih pravic) in ameriških pritiskov zašel v določeno slepo ulico (Baković 2021a; 2021b; Calder 2019, 178-179; Parker 1997, $81-84) .{ }^{17}$

Drugič, LR Kitajska v okviru PPC državam, ki

${ }^{14}$ Halford Mackinder je to misel izrazil prek geopolitičnega triptiha: »Kdor vlada vzhodni Evropi, vlada Osrčju [Evraziji]; kdor vlada Osrčju, vlada Svetovnemu otoku [Evropa, Azija in Afrika]; kdor vlada Svetovnemu otoku, vlada svetu." (Mackinder po Parker 1997, 84).

${ }^{15}$ Kitajski vojaški strategi se v svojih razmišljanjih izrecno sklicujejo na Halforda Mackinderja (International Crisis Group 2017, 5).

${ }^{16}$ Američani se v Vzhodni Evropi pozicionirajo prek širitve pakta NATO proti vzhodu, vzpostavljanja vojaških oporišč (na primer v Romuniji, Bolgariji in na Kosovu, verjetno pa kmalu tudi $\mathrm{v}$ Ukrajini) ter $\mathrm{v}$ zadnjih letih tudi preko ekonomsko-politične "Pobude treh morij» (Baltiškega, Črnega in Jadranskega).

${ }^{17}$ Letnega (on-line) sestanka »Okvira za sodelovanje 17 + 1«, ki je bil organiziran februarja 2021, se kar šest srednje- in vzhodnoevropskih članic (Estonija, Latvija, Litva, Romunija, Bolgarija in Slovenija) ni udeležilo s predsedniki vlad ali držav, kljub temu da je LR Kitajska zahtevala udeležbo na najvišji ravni, kajti v imenu Pekinga se je sestanka udeležil predsednik Xi Jinping. Maja 2021 je iz »Okvira za sodelovanje $17+1$ « izstopila Litva (Baković 2021a; 2021b). 
sodelujejo v projektu, ugodne kredite ponuja tudi prek treh finančnih institucij oziroma skladov, ki so bili v zadnjih letih ustanovljeni predvsem zaradi vztrajanja Pekinga, ki ima v njih tudi najpomembnejšo vlogo: Sklada svilne ceste (2014), z ustanovitvenim kapitalom 40 milijard dolarjev; Azijske banke za naložbe v infrastrukturo (2015), z ustanovitvenim kapitalom 100 milijard dolarjev; in Nove razvojne banke (2016) z ustanovitvenim kapitalom 100 milijard dolarjev. ${ }^{18}$ Pri tem je pomembno poudariti, da želi Peking prek teh finančnih institucij in skladov vzpostaviti finančni sistem, ki bi bil alternativa ameriško dominiranemu sistemu finančnih institucij, vzpostavljenem po drugi svetovni vojni (sistem iz Bretton Woodsa, ki vključuje Mednarodni denarni sklad, Svetovno banko in Svetovno trgovinsko organizacijo). LR Kitajska tudi na ta način sporoča, da želi odpraviti vodilno vlogo ZDA v svetu (Calder 2019, 95-97, 226-228; Maçães 2018, 48).

In tretjič, LR Kitajska želi s svojim ekonomskopolitičnim delovanjem (predvsem S P PC) tudi doseči veliki cilj ekonomskega in političnega integriranja Evrazije, kar bi bila velika novost oziroma sprememba $\mathrm{v}$ mednarodnih odnosih, saj je bil ta orjaški kontinent v vsej moderni zgodovini bolj ali manj fragmentiran in nepovezan. Pri tem si Peking lahko pomaga $\mathrm{z}$ nekaterimi procesi in dogodki, ki so se zgodili v zadnjih petih desetletjih: velika okrepitev kitajske moči na temelju »štirih modernizacij«; razpad Sovjetske zveze, ki je odprl možnost povezovanja s srednjeazijskimi republikami; globalna finančna kriza (2008), ki je razkrila ekonomske slabosti Zahoda, hkrati pa omogočila LR Kitajski, da je z ekonomskimi stimulusi bistveno prispevala k stabilizaciji položaja; in ukrajinska kriza (2013-2014), v kateri je Zahod z uvedbo sankcij proti Ruski federaciji le-to potisnil v kitajsko naročje. Vse večje integriranje Evrazije omogočajo tudi: energetska avtarkičnost in komplementarnost kontinenta (vsebuje največje proizvajalce in največje porabnike energentov); logistična revolucija (predvsem razvoj transportnih tehnologij), ki omogoča vse večje ekonomsko povezovanje med LR Kitajsko in EU (predvsem Nemčijo), tudi prek transkontinentalnih oskrbovalnih in proizvodnih verig; in finance (vse večja vloga azijskih, kitajsko vodenih finančnih institucij pri financiranju ogromnih infrastrukturnih potreb v Evraziji). Ker evrazijski kontinent po-

\footnotetext{
${ }^{18}$ Novo razvojno banko je LR Kitajska vzpostavila skupaj z drugimi članicami skupine BRICS (Brazilija, Rusija, Indija, Kitajska in Južna Afrika).
}

staja vedno bolj integriran, pa se tudi ekonomska in politična moč vse bolj selita iz atlantskega prostora v Evrazijo, kar seveda LR Kitajsko postavlja v poseben, vodilni položaj, ZDA pa posledično izgubljajo svoj vpliv v svetovnem okviru (Calder 2019, 49-99, 140-184). ${ }^{19}$

Proces povezovanja LR Kitajske in EU ter $s$ tem evrazijske integracije je bil še spodbujen $\mathrm{v}$ času Trumpove administracije, ki je s svojo politiko »Najprej Amerika« in z odpiranjem trgovinskih in varnostnih sporov $\mathrm{z}$ ameriškimi evropskimi zaveznicami Pekingu omogočala, da se je vse bolj povezoval s posameznimi državami članicami EU in z EU kot celoto.

Nova Bidnova administracija je s svojo politiko $\mathrm{v}$ zadnjega pol leta pokazala, da se $\mathrm{v}$ kontekstu tekmovanja med ZDA in LR Kitajsko za primat $\mathrm{v}$ svetu zaveda velike škodljivosti politik predhodne administracije. Biden zelo modro vodi politiko ponovnega privabljanja evropskih zaveznic k ZDA, in sicer $z$ odpravljanjem transatlantskih trgovinskih sporov, ameriškim prevzemanjem odgovornosti $v$ paktu NATO ter $z$ ustvarjanjem ameriško-evropske koalicije proti kitajski totalitarno-ultrarepresivni politiki do Ujgurov v Ksindžiangu. Vprašanje pa je, ali bo vse to zadostovalo za ustavljanje LR Kitajske na njeni poti proti vodstveni vlogi v svetu.

\section{Literatura}

"AI, Captain." 2020. The Economist, 26. september.

Allison, G. 2015. "The Thucydides Trap: Are the U.S. and China Headed for War?« The Atlantic, 24. september. http://www.theatlantic.com/international/ archive/2015/og/united-states-china-war -thucydides-trap/406756.

Baković, Z. 2021a. „Sestanek na konici injekcijske igle.» Delo, 11. februar.

- 2021b. »Dvostranski odnosi so še vedno v zamrzovalniku.« Delo, 27. maj.

Benko, V. 1997. Zgodovina mednarodnih odnosov. Ljubljana: Znanstveno in publicistično središče.

Calder, K. E. 2019. Super Continent: The Logic of Eurasian Integration. Stanford, CA: Stanford University Press.

Cox, M. 2017. "From the End of the Cold War to a New Global Era? «V The Globalization of World Politics: An Introduction to International Relations, 7. izd, ur. J. Baylis, S. Smith in P. Owens, 68-82. Oxford: Oxford University Press.

Dyer, G. 2014. The Contest of the Century: The New Era of Competition with China - and How America Can Win. New York in Toronto: Vintage.

\footnotetext{
${ }^{19} \mathrm{O}$ uveljavljanju osrednje vloge Evrazije v svetu govori npr. Pepe (2018).
} 
Frankopan, P. 2019. The New Silk Roads: The Present and Future of the World. London: Bloomsbury.

"Great White Hulls. " 2020. The Economist, 5. december.

Hillman, J. E. 2020. The Emperor's New Road: China and the Project of the Century. Washington, DC: Center for Strategic and International Studies.

Hurrell, A. 2017. »Rising Powers and the Emerging Global Order."V The Globalization of World Politics: An Introduction to International Relations, 7. izd., ur. J. Baylis, S. Smith in P. Owens, 83-97. Oxford: Oxford University Press.

International Crisis Group. 2017. "Central Asia's Silk Road Rivalries." Europe and Central Asia Report 245, International Crisis Group, Brussels.

Kennedy, P. 1988. The Rise and Fall of the Great Powers: Economic Change and Military Conflict from 1500 to 2000. London: William Collins.

Lawson, G. 2017. "The Rise of Modern International Order."V The Globalization of World Politics: An Introduction to International Relations, 7. izd., ur. J. Baylis, S. Smith in P. Owens, 37-51. Oxford: Oxford University Press.

"Living on the Edge." 2021. The Economist, 1. maj.

Maçães, B. 2018. Belt and Road: A Chinese World Order. London: Hurst.

Mackinder, H. 1919. Democratic Ideals and Reality. New York: Holt.
Mahan, C. A. T. 1987. The Influence of Sea Power Upon History: 1660-1783. Prenovljena izd. New York: Dover.

Medcalf, R. 2020. Indo-Pacific Empire: China, America and the Contest for the World's Pivotal Region. Manchester: Manchester University Press.

Parker, G. 1997. Zahodna geopolitična misel v dvajsetem stoletju. Ljubljana: Fakulteta za družbene vede.

Pepe, J. M. 2018. »Beyond China: The Return of the Eurasian Order." V Multipolarity: The Promise of Disharmony, ur. P. W. Schulze, 211-228. Frankfurt in New York: Campus.

Schulze, P. W. 2018. "Foreword.«V Multipolarity: The Promise of Disharmony, ur. P. W. Schulze, 7-11. Frankfurt in New York: Campus.

"Something Wicked This Way Comes." 2021. The Economist, 1. maj.

Šterbenc, P. 2012. »Tekma za Afriko.«Zgodovina v šoli 21 (1-2): $13-20$.

"The Beast from The East.« 2020. The Economist, 6. junij.

Tukidides. 1958. Peloponeška vojna. Ljubljana: Državna založba Slovenije.

Welch Larson, D., in A. Shevchenko. 2019. Quest for Status: Chinese and Russian Foreign Policy. New Haven in London: Yale University Press. 